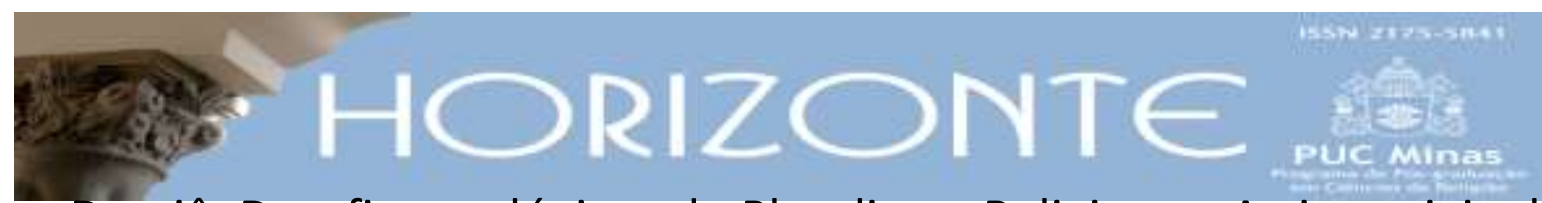

Dossiê: Desafios teológicos do Pluralismo Religioso - Artigo original (요요

\title{
Uma apologia do diálogo: Claude Geffré lendo Paul Tillich
}

\author{
An apology for dialogue: Claude Greffré reading Paul Tillich
}

Joe Marçal Gonçalves dos Santos*

\begin{abstract}
Resumo
O objeto deste artigo é a leitura que Claude Geffré faz de Paul Tillich em De Babel a Pentecostes: ensaios de teologia inter-religiosa. $\mathrm{O}$ autor recorre à teologia de Tillich para desenvolver uma "hermenêutica do diálogo inter-religioso", a fim de responder ao desafio do pluralismo religioso para a teologia cristã. O argumento que Geffré encontra é que apenas a partir do paradoxo cristológico, à luz do conceito de "revelação final" e "preocupação última", a teologia cristã pode responder ao pluralismo religioso sem perder-se de si mesmo. 0 artigo tem dois momentos: primeiro, uma percepção da obra de Geffré, especialmente a primeira parte, intitulada Não há outro nome, onde está nosso foco; segundo, a análise dos três conceitos de Tillich desenvolvidos por Geffré, procurando identificar e caracterizar acentos da leitura e analisar o resultado dessa leitura à luz das referências na obra de Tillich. Nossa conclusão sublinha a pertinência da teologia de Tillich para a reflexão acerca do problema proposto, tal como Geffré demonstra, e destaca uma crítica a partir do conceito de preocupação última, cuja implicação questiona a positividade desse conceito para uma teologia interreligiosa, uma vez que seu caráter paradoxal seja relativizado.
\end{abstract}

Palavras-chave: Pluralismo religioso; Paradoxo; Cristologia; Teologia inter-religiosa.

\begin{abstract}
The subject of this article is Claude Geffré's reading on Paul Tillich's thought in De Babel a Pentecostes: ensaios de teologia inter-religiosa. The author relies on Tillich's theology to develop an "inter-religious dialogue hermeneutics" in order to answer to the challenge that religious pluralism poses to Christian theology today. The argument that Geffré finds is that just based on the Christological paradox, in light of the concept of "final revelation" and "ultimate concern", Christian theology can respond to the religious pluralism without losing itself. The article presents two parts: firstly, an overview of Geffré's book, focusing on the first session entitled Não há outro nome, where our object of study is found. Secondly, we analyse Tillich's concepts developed by Geffré in this chapter, aiming to identify and characterize the main results of this reading and analyse them in light of Tillich's referential work. In conclusion, we highlight the relevance of Paul Tillich's theology to deal with the problem of religious pluralism, what is also demonstrated by Geffré. Besides, we consider a criticism of Gefreé's proposal regarding an inter-religious theology based on the concept of ultimate concern, whose implication questions the use of this concept for an inter-religious theology, as its paradoxical nature is relativized.
\end{abstract}

Keywords: Religious Pluralism; Paradox; Christology; Inter-religious Theology.

Artigo recebido em 31 de julho del 2015 e aprovado em 24 de novembro de 2015.

* Doutor em Teologia e professor do Núcleo de Ciências da Religião da Universidade Federal de Sergipe. País de origem: Brasil. E mail: jmgsantos@yahoo.com.br.

Horizonte, Belo Horizonte, v. 13, n. 40, p.1870-1895, out./dez. 2015 - ISSN 2175-5841 


\section{Introdução}

O objeto deste artigo é a leitura que Claude Geffré propõe de Paul Tillich em De Babel a Pentecostes: ensaios de teologia inter-religiosa, ${ }^{1}$ a fim de responder ao desafio que o pluralismo religioso impõe à teologia cristã hoje. O desafio compreende, basicamente, a relação entre sua autocompreensão e identidade e sua vocação de corresponder a seu tempo com o que lhe é atemporal, a saber, a fé que testemunha. Se a tarefa apologética moldou a teologia a partir do que é fundamental à fé cristã, isto é, sua reinvindicação absoluta do absoluto, como a transição a um novo paradigma, assentado no diálogo e na relacionalidade ecumênica, pode ser realizado sem a teologia resguardar-se, diluir ou perder-se de si mesma?

No que segue abaixo, desenvolvemos o argumento que o teólogo dominicano, Claude Geffré, encontra no teólogo protestante, Paul Tillich, para responder a essa questão. Em se tratando de buscar as bases para uma teologia em defesa do diálogo - uma apologia do diálogo -, é digno de nota que ela se dê a partir de tal encontro interconfessional. Nesse sentido, ambos são enfáticos: apenas a partir do seu fundamento cristológico em termos absolutos é que a teologia cristã pode "levar em consideração um pluralismo religioso de fato e se perguntar se ele não corresponde a um pluralismo religioso de princípio" (GEFFRÉ, 2013, p.7). A aparente contradição entre os termos é o que justamente nos encaminhará ao argumento principal de Geffré e Tillich: o paradoxo cristológico do universal que se torna concreto é chave hermenêutica para uma teologia dialógica e ecumênica, em lugar da dialética opositiva entre universal e concreto, ou fundamental e relativo que caracteriza a tradição teológica do Ocidente.

\footnotetext{
${ }^{1}$ Publicado originalmente pela Éditions du Cerf, Paris, 2006; a edição brasileira tem a tradução de Margarida M. Cichelli Oliva, e publicação pela Paulus, São Paulo, 2013.
} 
O texto desenvolve o tema em dois momentos: no primeiro, temos uma percepção da obra de Geffré, especialmente a primeira parte, intitulada Não há outro nome, onde está nosso foco de interesse; no segundo momento, analisamos os três conceitos de Tillich desenvolvidos por Geffré, procurando identificar e caracterizar acentos da leitura do primeiro pelo segundo.

\section{Não há outro nome: a teologia inter-religiosa de Claude Geffré}

\subsection{A moldura temática}

De Babel a Pentecostes, segundo o autor, aproveita o ensejo dos quarenta anos da publicação de Nostra Aetate, para oferecer uma visão abrangente do estado da arte da teologia das religiões que, nesse ínterim, se afirma como "uma teologia do pluralismo religioso que se interroga sobre o significado das diferentes vias para Deus no interior de seu unido desígnio criador e salvador" (GEFFRÉ, 2013, p. 8). Contudo, na medida em que constrói a percepção de uma nova configuração da teologia frente ao pluralismo religioso, uma vez que se aceite suas implicações, Geffré defende que "é preciso ir mais longe e tender para uma teologia inter-religiosa que reinterprete a singularidade cristã em função das riquezas de ordem religiosa de que podem ser testemunhas as outras religiões” (2013, p. 9).

O título do livro evidencia o que o autor reconhece no centro de seu interesse nos últimos anos: a mudança de paradigma a que a reflexão teológica cristã tem sido submetida desde que a relação entre cristianismo e outras religiões foi posta sobre novas bases. No Prefácio (2013, p. 5-10), Geffré indica uma de suas referências para pensar essa mudança: a epígrafe é selecionada dentre as conhecidas declarações de Paul Tillich quando, ao abordar o tema das "grandes religiões mundiais", percebe uma nova e decisiva demanda para a teologia a partir 
de "um diálogo criativo com o pensamento teológico das outras religiões" (TILLICH, 2005, p. 472). ${ }^{2}$

Em obra anterior, Geffré (2004) sinaliza as implicações envolvidas aqui, quando trata o pluralismo religioso como "paradigma" para a reflexão teológica como ele mesmo relembra no referido Prefácio (GEFFRÉ, 2013, p. 5). É verdade que o movimento ecumênico, que inicia mormente protestante, é o horizonte em que essa novidade vinga e se desenvolve ao longo do século $\mathrm{XX}$, animado especialmente pela ação missionária, de evangelização, cooperação e ajuda, desde a relação de igrejas protestantes europeias com as colônias nas Américas, África e Ásia. De modo geral, um processo orientado por um paradigma teológico marcadamente apologético, desde o qual o pluralismo religioso é algo a ser superado (2013, p. 315-316). Mas, de forma crescente, a teologia é interpelada e desafiada por um sentido de alteridade que ganhará expressão significativa apenas no Concílio Vaticano II - particularmente, através da Declaração Nostra aetate, que assenta a relação da Igreja Católica Romana com outras religiões em novas e inusitadas bases, fundando a chamada teologia das religiões. Esta, por sua vez, resulta do que Geffré define nos termos de uma "guinada hermenêutica" da teologia.

Na era da globalização, essa experiência da pluralidade de tradições religiosas coincide com uma consciência muito viva da relatividade da religião cristã, no concerto das religiões do mundo, e um conhecimento muito mais atento das outras religiões. Esse tempo corresponde, também, a uma nova era na ordem do pensável, a saber, a passagem da modernidade para o que alguns gostam de chamar de pós-modernidade e que posso, pelo menos, caracterizar como a passagem do saber absoluto para uma hermenêutica do testemunho (GEFFRÉ, 2013, p. 6 - grifo meu).

\footnotetext{
${ }^{2}$ Além da epígrafe do Prefácio, que cita o fim da Introdução ao terceiro volume - A Vida e o Espírito, A História e o Reino de Deus - da Teologia sistemática (TILLICH, 2005, p. 472), a alusão a esse episódio da biografia intelectual de Tillich está no capítulo em que Geffré concentra a leitura de sua obra, dando destaque à forma como o tema da correlação com as religiões ocupou Tillich em seus últimos escritos e conferências. Uma das suas experiências motivadoras foram seus encontros com intelectuais budistas japoneses na Universidade de Chicago, EUA, e suas conferências e debates na Universidade de Kioto, Japão - cf. Boss (2009), Ribeiro (2014)
} 
Resultado imediato dessa passagem é a "crise de credibilidade quanto à unicidade e à universalidade do cristianismo como sendo a única religião verdadeira, que detém a Boa-Nova da salvação para todo ser humano" (GEFFRÉ, 2013, p. 6). Isso explica a razão pela qual tal crise atinge a teologia cristã em seu âmago: ela recai sobre o paradigma desde o qual a teologia cristã surge, se desenvolve e se constitui ao longo da história: a defesa da verdade da religio licita em detrimento de outras religiões tornou a apologética o modus operandi da própria inteligência da fé. Mais que uma disciplina ou especialidade da teologia, a apologética define a racionalidade na qual a teologia tradicionalmente opera, orientada à defesa da fé verdadeira frente a outras religiões. Defesa esta baseada no sentido de absoluto em que a fé cristã se fundamenta e com o qual a igreja identificou a si mesma e sua tradição.

Por isso, não há novidade em a teologia dar-se "em relação a" outras religiões, pois que a defesa da verdade cristã implicou sempre, seja através da aproximação amigável ou da polêmica, na potência do falso atribuído às outras religiões. Por isso, a novidade a que a teologia das religiões acusa, e que Geffré define como paradigmática à teologia, é que essa relação constitutiva entre cristianismo e outras religiões ganha agora outra base teológica: ela se desloca do registro apologético e se situa em um paradigma dialógico e ecumênico.

Porém, antecede o diálogo certa afonia que a crise no fundamento acarreta. É a parte "Babel” da questão. Para superá-la, contudo, é preciso ir além do sentido punitivo que uma leitura moralizante do relato da torre sugere tradicionalmente. Na narrativa bíblica, Deus anda na cidade humana e percebe a húbris em que se assenta os fundamentos da torre: "Vamos construir uma torre que alcance os céus. Assim, nosso nome será famoso e não seremos espalhados pela face da terra" (Gênesis 11,4 - NVI)3. O interdito divino à construção da torre impede a realização imperiosa de alcançar "os céus" e, com isso, revela um sentido de juízo intrínseco e

${ }^{3}$ Esta e as demais citações do texto bíblico são da "Nova Versão Internacional” (NVI), conforme indicado nas Referências. 
paradoxalmente relacionado à graça de uma desilusão libertadora. Nas palavras de Geffré:

Contra a explosão das culturas, é preciso manter certa unidade do espírito humano. Mas, ao mesmo tempo, contra os perigos de um mundo unidimensional sob o signo da modernidade técnica, as tradições religiosas podem desempenhar um papel essencial para conservar e desenvolver a riqueza diversificada das culturas (GEFFRÉ, 2013, p. 25).

A referência que faz o autor à modernidade é significativa aqui, se considerarmos a unidimensionalidade a ela associada à luz do cristianismo e seu papel na formação da cultura ocidental. De todo modo, o desmantelo de um cristianismo imperioso e totalizante a partir da ótica da pluralidade religiosa é, poderíamos assumi-lo assim, correlativo a uma crítica religiosa à modernidade, radicalizada na noção de alteridade e de um princípio dialógico-ecumênico que, segundo Geffré, o encontro entre religiões reivindica (2013, p. 13-15). Eis a parte "Pentecostes" da questão: "Nós os ouvimos declarar as maravilhas de Deus em nossa própria língua" (Atos dos Apóstolos, 2,11b - NVI).

\subsection{Questões principais da teologia inter-religiosa}

A partir dessa moldura temática da teologia inter-religiosa delineada por Claude Geffré, ao analisarmos o plano da obra De Babel a Pentecoste, encontramos as questões principais que dão o corpo de sua proposta em três momentos: o primeiro, em referência a Atos dos Apóstolos (4,2 - NVI), intitula-se Não há outro nome, indicando de saída o argumento cristológico, respaldado pelo paradoxo do universal na história, no qual Geffré se baseia para pautar as implicações paradigmáticas do pluralismo religioso para a teologia. Nessa parte, o autor desenvolve sua percepção crítica de algumas das principais referências da teologia das religiões à luz de seu argumento central que, por sua vez, ganha atenção especial nos dois últimos capítulos dessa parte: o capítulo 5, no qual Geffré realiza sua leitura de Tillich, e o capítulo 6, em que assenta sua base epistemológica para 
uma teologia inter-religiosa, a saber, o paradoxo cristológico como hermenêutica do diálogo inter-religioso.

A segunda parte atende ao proposto no título Para uma teologia interreligiosa. Decisivo aqui é uma compreensão adequada do método comparativo para a teologia das religiões, assentada numa hermenêutica do diálogo interreligioso que tenha por referência o paradoxo cristológico. O objetivo de Geffré é tanto evitar recair, através do comparatismo, no paradigma apologético, quanto confundir teologia das religiões com história das religiões. Sobre essa base dialógica, os capítulos seguem explorando temas centrais do diálogo com o Islã e entre as três religiões monoteísticas a partir de desafios que o autor associa ao tema da modernidade, para finalizar com uma percepção do diálogo do cristianismo com novos movimentos religiosos de orientação New age.

A terceira parte do livro reúne ensaios em torno do tema da Missão $e$ inculturação, propondo novamente desenvolver implicações a partir do paradigma dialógico-ecumênico. Critério básico dessa reflexão é que "não devemos nos referir, apressadamente, à universalidade da salvação em Jesus Cristo para justificar a pretensão universalista do cristianismo como religião histórica" (GEFFRÉ, 2013, p. 315). Todo o desenvolvimento dessa parte se desdobra em torno da distinção fundamental dada a partir da relação entre o absoluto $e$ o concreto, o universal e o particular no paradoxo cristológico. É para desenvolver essa relação e assenta-la como "hermenêutica do diálogo inter-religioso" que Geffré investe na leitura de Paul Tillich, a qual passamos a analisar.

\section{Três conceitos de Paul Tillich na ótica de Claude Geffré}

Como vimos acima, o pluralismo religioso implica para a teologia em uma nova base de relação entre cristianismo e outras religiões, amplificando o sentido da ecumene no diálogo inter-religioso. Para desenvolver as referências dessa amplificação do conceito, Geffré recorre a noções fundamentais da teologia de Paul 
Tillich, segundo a qual, como a entende Geffré (2013, p. 88), "não podemos mais reservar a palavra 'ecumenismo' para o diálogo entre as confissões cristãs”.

Trata-se de uma exigência histórica que, com Tillich, compreendemos à luz do conceito de kairós: "momento em que a história - em uma situação concreta amadurecera a ponto de poder receber a irrupção da manifestação central do Reino de Deus" (TILLICH, 2005, p. 800). O modo como Geffré define o pluralismo religioso ganha essa qualidade kairótica, de revelar uma nova e original percepção do símbolo teológico de Reino de Deus como hermenêutica teológica da história e das condições de existência na contemporaneidade.

A percepção do desenvolvimento da teologia da religião empreendida por Geffré, como também vimos acima, nesse sentido, oferece os contornos do "grande consenso" na teologia contemporânea de não se tomar o cristianismo como "modelo religioso exclusivo", seja pela via eclesiocêntrica tipicamente católica ou a partir de um protestantismo que radicalize a "religião da graça" no cristianismo (GEFFRÉ, 2013, p. 88-89). Contudo, esse é ainda um consenso apenas na negação de um modelo, frente ao que permanece uma "tensão fundamental": de um lado, o princípio dialogal, que exige "igualdade e reciprocidade", e, de outro lado, "a legítima pretensão do cristianismo como religião da manifestação absoluta e definitiva de Deus em Jesus Cristo" (2013, p. 89). Qualquer solução rápida demais dessa tensão, na qual tanto aquilo que é exigido, quanto o que fundamenta a recepção dessa exigência para o cristianismo sofra alguma compensação ou diluição de sua normatividade, tem de responder pela hermenêutica que realiza, e por conseguinte, pelo círculo hermenêutico em que se situa.

Desse modo, Geffré chama atenção para as implicações de uma solução tácita a qual a teologia das religiões tem recorrido, de relativizar seu fundamento quando, na visão de Geffré, apoiando-se em Tillich, apenas na fidelidade incondicional ao fundamento, definido como paradoxo, é que a teologia pode responder a essa questão. Esse é o núcleo do problema que motiva Geffré em sua 
argumentação. Ele é categórico ao afirmar a insuficiência de um consenso em torno da negação de um modelo, em vista do que permanece ausente:

Em outras palavras, não é certo que já dispomos de uma resposta teológica adequada, que leve a sério as implicações do diálogo interreligioso sem sacrificar a identidade cristã. (...) Em vez de adotar um teocentrismo geral em sentido liberal, é a partir do centro mesmo da mensagem cristã, a saber, a manifestação de Deus na particularidade histórica de Jesus de Nazaré, que é preciso dar prova do caráter necessariamente dialogal do cristianismo, isto é, exorcizar sua pretensão totalitária (GEFFRÉ, 2013, p. 89 - grifos do autor).

Quer dizer, para Geffré, responder à exigência de diálogo do pluralismo religioso, tomando-a como implicação kairótica de nossa situação históricocultural, ainda que implique em certa tensão com a exigência da centralidade da reinvindicação do Absoluto no Cristianismo, não significa sua negação. Pelo contrário:

Em vez de renunciar à confissão de Jesus Cristo como Absoluto, prefiro dizer que o cristão deve renunciar a qualquer pretensão de verdade absoluta, precisamente por confessar Jesus Cristo como Absoluto, isto é, como plenitude escatológica que jamais será revelada na história (GEFFRÉ, 2013, p. 90).

Partindo desse ponto, Geffré ” (2013, p. 90) aceita o convite de Paul Tillich para "meditar sobre o paradoxo do cristianismo como religião não absoluta que, ao mesmo tempo, entretanto, dá testemunho da revelação final.

\subsection{O paradoxo cristológico do Jesus como o Novo Ser}

O desafio do qual se parte, conforme Geffré (2013, p. 91), é a ambiguidade entre "estarmos prontos a aceitar a particularidade histórica do cristianismo", o que a exigência de diálogo reivindica em meio ao pluralismo religioso, e, ao mesmo tempo, reivindicar "para o cristianismo uma unicidade de excelência que não se compara a nenhuma outra", implicado na confissão de Jesus como o Cristo. 
Contudo, a primeira coisa a se fazer aqui é traçar a relação entre ambas exigências na mesma fé: a aceitação da dimensão histórica do cristianismo e reivindicação da unicidade do Cristo se implicam mutuamente e estão sobre a mesma base, que é a própria confissão da pessoa de Jesus de Nazaré como o Cristo de Deus.

Para traçar tal relação, contudo, é preciso assumi-la paradoxalmente e perceber que justamente enquanto paradoxo ela se torna critério fundamental para a teologia, também a partir do novo paradigma do pluralismo religioso. Com Paul Tillich, Geffré segue o argumento de que o

paradoxo, em teologia, não é contrário a uma exigência de racionalidade lógica. O paradoxo não decorre de uma contradição lógica, mas do fato de um acontecimento [sic] que transcende todas as expectativas e possibilidades humanas (GEFFRÉ , 2013, p. 92).

Para defini-lo nesses termos, Geffré recorre a Teologia sistemática, numa passagem em que Tillich desenvolve os "motivos do simbolismo trinitário" (TILLICH, 2005, p. 721-724). O argumento de Tillich nestas páginas dedica-se a descaracterizar a Trindade como paradoxo, considerando-a como símbolo para os processos da vida, o que "nos levou à discussão de Deus como fundamento, Deus como forma e Deus como ato, uma fórmula pré-trinitária que conferia sentido ao pensamento trinitário" (2005, p. 722). Por isso,

os símbolos trinitários são dialéticos; eles refletem a dialética da vida, a saber, o movimento de separação e reunião. A afirmação de que três é um e um é três foi (e, em muitos lugares, ainda é) a pior distorção do mistério da Trindade. Se a entendermos numericamente, ela representa uma charada ou um puro absurdo. Se for entendida como a descrição de um processo real, ela não é paradoxal ou irracional, mas uma descrição precisa de todos os processos da vida. E na doutrina trinitária ela é aplicada à vida divina em termos simbólicos (TILLICH, 2005, p. 722).

A importância desse pano de fundo do argumento do paradoxo é perceber que Tillich difere da teologia dialética em um ponto central, que é a cristologia. 
Não se trata de estender o paradoxo como "racionalidade" teológica de modo geral, mas de toma-lo como fundamento daquilo que se reconcilia em Deus: "se Deus é experienciado como Deus vivo e não como uma identidade morta, deve haver um elemento de não-ser no ser de Deus, isto é, o estabelecimento de uma alteridade" (TILLICH, 2005, p. 722). Daí a citação feita por Geffré (2013, p. 92): a base para tal está no único "paradoxo na relação entre Deus e o ser humano, e ele consiste na aparição de sua unidade eterna ou essencial sob as condições de sua separação existencial” (TILLICH, 2005, p. 722), isto é, o paradoxo cristológico.

É, contudo, no segundo volume da Teologia sistemática que Tillich desenvolve de modo específico esse tema, a partir da correlação entre a pergunta da existência e Cristo. Procedimento recorrente de Tillich é a análise semântica dos termos e conceitos tradicionais em teologia, identificando seus potenciais e limites. A noção de paradoxo, segundo ele, é também refém de abusos históricos que exigem "distinguir paradoxal do reflexivo-racional, do dialético-racional, do irracional, do absurdo e do sem sentido" (TILLICH, 2005, p. 382). Após dedicar alguns parágrafos a esse exercício crítico, Tillich depreende o sentido afirmativo do termo paradoxo:

É paradoxal aquilo que contradiz a doxa, a opinião que se baseia no conjunto da experiência humana comum, incluindo o empírico e o racional. O paradoxo cristão contradiz a opinião derivada da condição existencial do ser humano, e todas as expectativas imagináveis à base dessa condição. O caráter paradoxal da mensagem cristã não é uma "ofensa" às leis do discurso inteligível, mas à interpretação habitual do ser humano com respeito a si mesmo, a seu mundo e à realidade última subjacente a ambos. É uma ofensa à confiança inquebrantável do ser humano em si mesmo, às suas tentativas de auto-salvação e à sua resignação distante do desespero. Contra cada uma dessas três atitudes a manifestação do Novo Ser em Jesus como o Cristo é juízo e promessa. A aparição do Novo Ser sob as condições da existência, mas julgando-as e vencendo-as, é o paradoxo da mensagem cristã. Esse é o único paradoxo e a fonte de todas as afirmações paradoxais no cristianismo (TILLICH, 2005, p. 383-384).

É nessa percepção que Tillich assenta a noção, aparentemente nada modesta, de que a teologia cristã é a teologia: contudo, enfaticamente isto não se 
dá em razão de um conteúdo privilegiado, objetivo, que tenha sido revelado como tal, sem mediações concretas, a um povo, lugar e tempo; o conteúdo do cristianismo é tão simbólico, mediativo e concreto quanto o de qualquer religião. Seus símbolos expressam concretamente o que o cristianismo recebeu como revelação. Sua teologia é a teologia porque "o princípio da auto-revelação divina se tornou manifesto no evento 'Jesus como o Cristo'” (TILLICH, 2005, p. 33). Em outras palavras, nesse evento Deus revela seu modo de se revelar - o que a tradição cristã expressou com o símbolo "o Logos se tornou carne". 4

A teologia cristã recebeu algo que é absolutamente concreto e, ao mesmo tempo, absolutamente universal. Nenhum mito, nenhuma visão mística, nenhum princípio metafísico, nenhuma lei sagrada tem a concretude de uma vida pessoal. Em comparação com uma vida pessoal, tudo o mais é relativamente abstrato. E nenhum desses fundamentos relativamente abstratos da teologia tem a universalidade do Logos, que é ele mesmo o princípio da universalidade (TILLICH, 2005, p. 33).

A falta de modéstia é, segundo entende Geffré, aparente. Em um escrito de 1925, Dogmatik, Tillich se posiciona frente à crítica da história das religiões, afirmando o princípio crítico do incondicional - conceito determinante em seu pensamento, que nessa época é desenvolvido especialmente em sua Religionphilosophie (Filosofia da religião, de 1925) e, antes, no artigo Die Überwindung des Religionsbegriffs in der Religionphilosophie (A superação do conceito de religião na filosofia da religião, de 1922) (TILLICH, 1987). Como parafraseia Geffré, para Tillich, “o paradoxo Absoluto da fé consiste no 'não' absoluto e no 'sim' absoluto que Deus pronuncia a respeito da mesma pessoa humana" (GEFFRÉ, 2013, p. 93), destacando que a "lei do paradoxo Absoluto se encontra em toda experiência religiosa na qual o elemento Absoluto desempenha o papel de uma norma crítica incondicional de qualquer determinação concreta"

\footnotetext{
${ }^{4}$ A tradição cristã em questão aqui poderia ser precisada, a partir das bases filosóficas e teológicas na qual Tillich opera. A noção hegeliana do universal concreto está bem presente aqui, modulada, porém, pelo romantismo místico de Schelling e da teologia de Schleiermacher. Estes evocam especialmente a implicação subjetiva do universal concreto, em torno da "intuição" como dimensão da racionalidade que permite realizar o que a tradição teológica liberal expressou como finitum capax infiniti (o finito é capaz do infinito).
} 
(GEFFRÉ, 2013). O que, contudo, é importante sublinhar aqui é que tal lei do paradoxo Absoluto "só pode se tornar efetiva através dessa determinação concreta" que a media e sobre a qual recai a exigência incondicional (GEFFRÉ, 2013). Nisto reside o elemento paradoxal do conceito de incondicional, cujo papel é determinante na obra de Tillich, perpassando diferentes escritos em diferentes momentos de sua vida, atuando como um leitmotiv, do qual uma das explicitações mais significativas encontramos em Dinâmica da fé:

O realmente incondicional deixa infinitamente atrás de si todo o âmbito do condicionado. Por isso ele não pode ser expresso direta e adequadamente por nenhuma realidade finita. Falando em termos religiosos, isso que dizer: Deus transcende o seu próprio nome (TILLICH, 2001, p. 32-33).

$\mathrm{Na}$ sistemática, a tensão entre incondicional e condicionado na base da teoria fenomenológica do sentido que orienta a Filosofia da religião (TILLICH, 1987, p. 133-134) modula-se no argumento ontológico da distinção entre essência e existência, da qual decorre a condição de alienação da vida em relação a sua própria essência (TILLICH, 2005, p. 210).5 Sob essas categorias Tillich desenvolve sua cristologia, sintetizado na doutrina do Novo Ser em Jesus como o Cristo: “O Novo Ser é o ser essencial que, sob as condições da existência, transpõe o abismo entre essência e existência" (TILLICH, p. 408). Nas palavras de Geffré,

A função essencial de Cristo como Ser novo (New Being) é de salvar o homem de sua alienação e de renovar o universo. Em Jesus confessado como o Cristo manifestou-se o Ser novo (New Being) que está no princípio da transformação de toda existência histórica e da renovação de toda a criação (GEFFRÉ, 2013, p. 95). ${ }^{7}$

\footnotetext{
${ }^{5}$ No desenvolvimento de sua sistemática, Tillich se desloca de uma teoria do sentido a uma teoria do ser. Com isso, ele redimensiona a teologia da cultura precisamente "quando o fundamento ontológico do ser é identificado como o fundamento incondicional de todo ato de sentido". Na perspectiva da revelação, significa que a incondicionalidade de sentido que fundamenta a criatividade cultural (poder de sentido) é também o mistério da própria vida (poder de ser), e a crítica dirigida contra uma situação cultural vazia de sentido se assenta no que ela compromete a vida em suas diferentes dimensões - cf. introdução ao segundo volume das obras principais de Tillich, por Michael Palmer (1990, p. 2-4).

${ }^{6}$ Geffré conclui: “A cristologia de Paul Tillich não especula sobre a união de Deus e o homem em Jesus Cristo. Mas mesmo que ele não privilegie o termo não bíblico de encarnação por causa das conotações pagãs, jamais ele aceitaria dizer que a filiação divina de Jesus não passa de uma "metáfora". Isso seria comprometer a identidade de Jesus e Cristo, e a cristologia viria a ser uma jesuologia. Se quisermos ir até o fim das implicações da doutrina de Cristo como Ser novo (New Being), é preciso compreender que Cristo só é Cristo na medida em que sacrifica sua existência histórica como existência d'Aquele que é simplesmente Jesus" (2013, p. 97).
} 
Conforme Tillich, a manifestação do Novo Ser em Jesus como o Cristo implica, portanto, que o paradoxo cristológico - para corresponder ao Absoluto paradoxo - tem de instituir sua própria crítica.

Só como o crucificado ele é "graça e verdade" e não lei. Só como aquele que sacrificou sua carne, isto é, sua existência histórica, ele é Espírito ou Nova Criatura. Esses são os paradoxa nos quais se manifesta o critério da revelação final. Mesmo o Cristo só é Cristo porque não insistiu em sua igualdade com Deus, mas despojou-se dela enquanto posse pessoal (Fp 2) (TILLICH, 2005, p. 145).

Nesse ponto a exclusividade cristológica e a exigência do diálogo equitativo entre religiões deixam de ser uma ambiguidade conflitiva. Pois, a teologia da cruz "fornece o fundamento para suprimir o caráter de absoluto do cristianismo como religião histórica", e assim, "renunciar a conferir ao cristianismo uma unicidade de excelência e de integração e reivindicar apenas uma unicidade singular e relativa (GEFFRÉ, 2013, p. 97-98 - grifo meu). O argumento kenótico sugerido por Tillich em sua menção à carta paulina, em Filipenses 2, enseja a conclusão de Geffré:

o cristianismo está sempre sob o signo de um falta. É a kénosis de Cristo na sua igualdade com Deus que permite a ressurreição no sentido mais amplo da palavra, mas é também o túmulo vazio, a ausência do corpo do fundador que é a condição do advento do corpo da Igreja e do corpo das Escrituras (GEFFRÉ, 2013, p. 98). ${ }^{8}$

Assim, no que diz respeito à tensão conflitiva entre a exigência implicada no diálogo e a exigência implicada na fé cristã para o ecumenismo, Geffré encontra resposta em Tillich, mais precisamente, no seu modo de atender à exigência da fé

\footnotetext{
${ }^{7}$ Faço aqui a nota crítica à edição brasileira do livro de Geffré, por não ter se valido da $5^{\mathrm{a}}$ edição revista da Teologia sistemática de Tillich, e assim ter destoado da formulação de alguns conceitos importantes - a exemplo de "Ser novo" ao invés de "Novo Ser" - que vigoram na recepção e pesquisa do autor no Brasil.

${ }^{8}$ Em nota de rodapé, Geffré credita o tema da "falta" a Michel de Certeau (ver nota 16, p. 99). Digno de nota, essa noção, aproximada ao conceito de incondicional em Tillich, enfatiza o caráter crítico negativo do conceito, mas - talvez em função de uma substancialidade católica, própria a teologia de Certeau e Geffré - esse "vazio" torna-se justamente o lugar em que a fé no crucificado "ganha corpo". Essa perspectiva fornece um argumento significativo para trabalhar o conceito de "vazio sagrado" ao qual Tillich (1990, p. 197-207; p. 269-79; p. 297-302) recorre em suas análises existências da arte moderna; embora, contudo, o defina a partir e de modo aparentemente exclusivo a partir do princípio protestante.
} 
cristã a partir da aceitação do paradoxo, que é simultaneamente fundamento e abismo: "Para a fé cristã de sempre, Jesus é bem a identificação do Deus pessoal [...] Mas essa identificação paradoxal remete a um Deus invisível que escapa a qualquer identificação" (GEFFRÉ, 2013, p. 99).

\subsection{A noção de revelação final e o paradoxo da religião cristã}

Já antecipamos o argumento da revelação final acima, quando referíamos a uma aparente falta de modéstia na afirmação de que a teologia cristã só entende-se como tal quando na sua unicidade: ela é a teologia - a partir do critério material fundante, a revelação final implicada na doutrina do Novo Ser em Jesus como o Cristo. O seu caráter final consiste em ser essa revelação a revelação da própria automanifestacão divina, em relação a qual toda outra revelação é dependente (TILLICH, 2005, p. 138-140).

Isso coloca o cristianismo sob o paradoxo no qual ele se fundamenta e que confere sua exclusividade: se o cristianismo é "a religião da revelação final, ele exclui toda pretensão à incondicionalidade da parte de uma via de revelação particular, a começar pela sua própria” (GEFFRÉ, 2013, p. 100-101).

A tese é assim formulada: "Uma revelação é perfeita quando sua via de salvação supõe o abalo de toda via de salvação” (TILLICH apud GEFFRÉ, 2013, p. 102). ${ }^{9}$ Quer dizer, a exclusividade do cristianismo está em sua recepção concreta daquilo que é incondicional e último, a saber, que no evento de Jesus de Nazaré ser confessado como o Cristo - pois "o Cristo não seria o Cristo sem as pessoas que o recebem como Cristo" (TILLICH, 2005, p. 602) -, Deus se revela assumindo as condições da existência sem ser por ela reduzido e, dessa maneira, manifesta o Novo Ser como possibilidade e, ao mesmo tempo, limite para toda a existência. É assim que "o paradoxo da revelação perfeita deriva do fato de que ela deve

\footnotetext{
${ }^{9}$ Geffré remete aqui, novamente, a Dogmatik de Tillich, de 1925, cuja publicação se deu apenas em 1986 e não está, portanto, nos volumes da Main Works/Hauptwerke. $\mathrm{O}$ acesso ao texto por Geffré se dá pela edição francesa, conforme a apresenta na nota 6, p. 93.
} 
conciliar, em si mesma, o duplo aspecto da realização concreta e do protesto que faz irrupção e provoca o abalo" (GEFFRÉ, 2013, p. 102).

Sob esse paradoxo, que é o paradoxo do incondicional, toda pretensão a uma via concreta de sentido último, ou toda religião particular é colocada sob crise - inclusive o cristianismo. Ao mesmo tempo, contudo, esse mesmo paradoxo assenta a possibilidade concreta de sentido último e incondicional em toda religião particular, que é afirmada paradoxalmente, isto é, simultaneamente a seu juízo frente ao incondicional. Numa palavra, "onde está o sagrado também está o profano. (...) À ambiguidade da vida pertence o fato de que ambas as qualidades, o sagrado e o profano, estejam sempre presentes em suas estruturas" (TILLICH, 2005, p. 546-547).

Embora haja nisso um elemento trágico, relativo à ambiguidade estrutural da vida em suas diferentes dimensões, também nisso se assenta a grandeza da vida como possibilidade de realização de sentido incondicional. Geffré deduz desse argumento, no que diz respeito às religiões, o que fundamenta a ideia de uma teologia inter-religiosa. Em suas palavras:

Isso nos convida a ultrapassar o ponto de vista relativista da história das religiões e a buscar um fundamento teológico para o pluralismo religioso. O pluralismo religioso não é somente um pluralismo de fato, ligado a uma situação histórica contingente. É um pluralismo de direito, fundado sobre a necessária desqualificação de absoluto de toda religião histórica como encarnação da revelação final. Desse modo, a regra prática que deveria comandar o ecumenismo inter-religioso do futuro seria de não confundir a questão da verdade do cristianismo com a de sua superioridade. Em nome da fé cristã, é nessa via de salvação concreta inaugurada por Jesus Cristo que recebo a revelação final sobre Deus, sobre o mundo e sobre o homem. Mas deixo aberta a questão de saber se a revelação final pode ser alcançada nas outras religiões (GEFFRÉ, 2013, p. 102).

Evidentemente, aqui se deve manter em foco o caráter crítico-negativo do paradoxo em que se fundamenta a revelação que reivindica ser final. Isso porque é inevitável retornar à pergunta sobre como pode o cristianismo reivindicá-lo e 
justificar essa pretensão. Em se tratando da revelação final, é dela mesma que o critério de justificativa e pretensão deve ser deduzido. Assim,

A primeira e fundamental resposta que a teologia deve dar à questão do caráter final da revelação em Jesus como o Cristo é a seguinte: uma revelação é final se tem o poder de negar-se a si mesma sem perder a si mesma (TILLICH, 2005, p. 144).

Por isso, ao levantar a "questão lancinante" quanto à pretensão do cristianismo em afirmar - note-se que não se trata de afirmar-se - a qualidade de revelação final do Novo Ser em Jesus como o Cristo, de imediato, Geffré (2013, p. 103) associa tal pretensão à "incondicionalidade da fé", pois que a negação de si mesmo é o critério de "novidade de ser" em Jesus como o Cristo, "que sacrificou sua existência histórica” sem perder-se de si mesmo enquanto Jesus de Nazaré.

A partir desses elementos, e assumindo a crise do próprio cristianismo sob o critério do paradoxo, torna-se necessário recorrer a uma categoria eclesiológica mais ampla para tratar da "comunidade" humana movida pela Presença Espiritual (TILLICH, 2015, p. 567-575) no mundo e na vida. Nesse sentido, propõe Tillich, a noção de comunidade espiritual define a realização do que supera as ambiguidades da própria religião:

A Comunidade Espiritual é sem ambiguidade, é o Novo Ser criado pela Presença Espiritual. Mas, embora seja uma manifestação da vida sem ambiguidade, ela é fragmentária, como o foi a manifestação da vida sem ambiguidade no Cristo e nas pessoas que esperaram o Cristo. A Comunidade Espiritual é uma criação não-ambígua, embora fragmentária, do Espírito divino. Nesse contexto, "fragmentário" significa que ela aparece sob as condições da finitude, mas supera tanto a alienação quanto a ambiguidade (TILLICH, 2005, p. 602-603).

Para evitar a ambiguidade implicada no termo "igreja", Tillich opta pelo conceito de Comunidade Espiritual, do qual depreende a distinção entre igreja manifesta e latente, em evidente referência à distinção luterana entre igreja visível e invisível. Geffré, contudo, defende que "é preciso ir além da linearidade 
cronológica, e chamar de Igreja em estado latente toda a comunidade espiritual de antes ou depois de Cristo" (GEFFRÉ, 2013, p. 107), tendo em mente que

\begin{abstract}
a Comunidade Espiritual não é um grupo ao lado de outros grupos, mas um poder e uma estrutura inerentes e efetivos nestes grupos, isto é, nas comunidades religiosas. Se eles se baseiam explicitamente no aparecimento do Novo Ser em Jesus como o Cristo, estes grupos se chamam igrejas. Se possuem outros fundamentos, chamam-se sinagogas, congregações de templos, grupos de mistério, grupos monásticos, grupos e movimentos cultuais. Na medida em que estão determinados por uma preocupação última, a Comunidade Espiritual está presente, em seu poder e estrutura ocultos, em todos estes grupos (TILLICH, 2005, p. 614).
\end{abstract}

Assim, a partir desse conceito, Tillich radicaliza um princípio de ecumenicidade, apontando para aquilo que está implicado no poder da Comunidade Espiritual, que é não apenas o sentido de Absoluto, mas, ao mesmo tempo, de sua incondicionalidade - e o conceito que Tillich cunha para expressá-lo é preocupação última (ultimate concern).

\title{
2.3 Ultimate concern: horizonte de diálogo e ecumenicidade
}

O terceiro e último conceito de que Geffré se apropria, a fim de lançar bases epistemológicas para a teologia inter-religiosa, é a conhecida noção de preocupação última ou preocupação incondicional. Com ela, Tillich (2005, p. 5455) define religião, em sentido lato, como "profundidade da cultura", e especialmente, refere-se a essa noção para sua definição de fé em Dinâmica da fé, como "estado de estar possuído por aquilo que nos toca incondicionalmente" (TILLICH, 2001, p. 5).

A eleição deste conceito como critério para o encontro entre religiões é significativa, porque Tillich o desenvolve especialmente em um sentido crítico. "A expressão 'preocupação incondicional' indica dois lados de um relacionamento: ela mostra para aquele que por ela é possuído [e] para aquilo que o possui” (TILLICH, 
2001, p. 10). Quer dizer, o fato de o ser humano poder ser afetado por preocupações últimas indica sua potência autotranscendente e a capacidade de intuir sentido incondicional naquilo e por meio daquilo que o cerca (TILLICH, 1973, p. $37-56) .{ }^{10}$

Uma vez entendido isto, compreende-se também por que quase tudo "no céu e na terra" já alcançou o caráter do incondicional no decurso da história da religião. Mas também podemos compreender que na consciência religiosa do homem [sic] sempre já esteve e ainda está agindo um princípio crítico, o qual procura separar o que é realmente incondicional daquilo que reivindica para si o caráter de incondicional, mas na realidade é apenas provisório, passageiro e finito (TILLICH, 2005, p. 11).

Este "princípio crítico" da consciência humana é o que Tillich define como princípio protestante, que age na atividade espiritual humana em todas as esferas culturais - religiosa, artística, política etc. - como uma vigilância ou suspeita em relação a tudo o que reivindica incondicionalidade (2005, p. 686-687). É um princípio relativo à ambiguidade da fé e da religião, cuja função, segundo Tillich, é distinguir a falsa e a verdadeira incondicionalidade a partir do seguinte critério:

Em expressões como de validade última, incondicional, infinito, absoluto está superada a distinção entre subjetivo e objetivo. O estar tomado incondicionalmente no ato da fé, e o incondicional, que é experimentado no ato de crer, são uma coisa só. (...) Pode-se formular abstratamente a mesma experiência como sendo a anulação da contraposição sujeito-objeto na experiência do incondicional. (TILLICH, 2005, p. 12 - grifo do autor).

Isso porque a verdadeira incondicionalidade abraça o caráter kenótico do incondicional, isto é, a ausência de uma objetivação positiva identificada ao incondicional. Sob esse critério define-se a fé idólatra: esta resiste à falta de objetivação do incondicional e não consegue superar a separação entre sujeito e

\footnotetext{
${ }^{10}$ Como acima referimos (nota 4), a base teológico-filosófica de Tillich (1973, p.37-56) se assenta na tradição protestante liberal. Vale lembrar, contudo, que os principais escritos filosóficos de Tillich são fruto de sua revisão dessa tradição após a Primeira Guerra. Ele não abondona essas referências de forma absoluta, mas a modula a partir de sua apropriação da crítica do existencialismo, do marxismo e do pragmatismo, bem como da revisão neokantiana que determinava o ambiente intelectual da Alemanha nos anos de 1920. Nessa "fronteira", Tillich elabora o que chama de método metalógico como método adequado à filosofia da religião.
} 
objeto que apenas a experiência do incondicional realiza. Por isso, a idolatria "eleva coisas passageiras e finitas à categoria de incondicionais", preenchendo a falta, ou o "vazio sagrado", com algo a que possa agarrar-se. E essa ambiguidade inerente à fé se estende à dinâmica do sagrado como tal:

O santo ou sagrado em princípio nada tem a ver com a alternativa bom e mau: ele é tanto divino como demoníaco. (...) O sagrado, na medida em que atua demoníaca e por isso destrutivamente em última instância, é idêntico com o objeto da fé idólatra. Mesmo assim também a fé idólatra ainda é fé. O sagrado também permanece sagrado em sua forma demoníaca. Aqui se manifesta nitidamente o caráter ambíguo da religião e com isso também o perigo da fé. $O$ perigo da fé é a idolatria, e a ambiguidade do sagrado resulta de sua possibilidade demoníaca. Nossa preocupação última - aquilo que nos toca incondicionalmente - pode nos destruir assim como também pode nos curar. Mas sem uma preocupação última não podemos viver (TILLICH, 2001, p. 15).

Por sua vez, conforme Tillich, corresponde à fé verdadeira a coragem de aceitar o risco implicado no paradoxo do incondicional, que ao tempo em que é fundamento é também abismo sobre o qual nada se estabelece ou nada se pode dizer. Nesse caso, correlativamente ao "ídolo", que é a objetivação do incondicional em algo condicionado, a fé se vale do símbolo para expressar o incondicional (TILLICH, 2001, p. 30). A diferença fundamental entre ídolo e símbolo é que este último aceita e se afirma no paradoxo do incondicional: "Deus transcende seu próprio nome” (GEFFRÉ, 2013, p. 33).11

A partir desse exame da preocupação última, voltamos à proposta de Geffré, de tomar esse conceito como "base comum sobre a qual fundamentar um diálogo" entre as religiões (GEFFRÉ, 2013, p. 109). As implicações decorrem fundamentalmente do caráter crítico desse conceito. Geffré mesmo sublinha isso ao iniciar ponderando que, assim como a noção de "Deus, reconhecido como Transcendência pessoal" (GEFFRÉ, 2013, p. 109) não pode ser tomada como "base

\footnotetext{
${ }^{11}$ Ao referir à crítica que Tillich faz à doutrina da encarnação, Geffré afirma que, ainda assim, "jamais ele aceitaria dizer que a filiação divina de Jesus não passa de uma 'metáfora'” (2013, p. 97). Seria o caso de saber o que Geffré entende por metáfora aqui. Pois que, se for análogo a noção de símbolo de Tillich, teríamos de considerar que não se trata de "não passa de" mas "é nada menos que" uma metáfora.
} 
de diálogo", também o "critério do humano verdadeiro não é específico do diálogo entre as religiões” (GEFFRÉ, 2013, p. 110).

Parece, portanto, preferível recorrer a um critério ecumênico que dependa da antropologia religiosa e da filosofia da religião. E é aí que verificamos a pertinência sempre atual da visão de Tillich relativa ao incondicional ou à "preocupação última". [...] De acordo com a visão de Tillich, podemos distinguir uma "fé fundamental" e um conjunto de crenças (beliefs) relativas às verdades particulares, ou a regras da vida. [...]. É na ordem da "fé fundamental" que as diferentes religiões se assemelham, e é segundo suas "crenças" que elas se distinguem e até se defrontam em virtude dos desacordos fundamentais (GEFFRÉ, 2013, p. 110).

A distinção que propõe Geffré entre "fé fundamental" e "crenças" merece uma análise mais cuidadosa. Na verdade, ela repercute da discussão que Tillich desenvolve em Dinâmica da fé, quando, após assentar o conceito de "o que a fé é", em termos fenomenológicos, distingue "o que a fé não é" a partir de suas reduções a "ato de conhecimento", "ato de vontade" e "sentimento" (TILLICH, 2001, p. 24$30)$.

Contudo, o mais importante, à distinção de Geffré escapa o caráter crítico do conceito de Tillich, o que tem implicações se a tomarmos como critério de encontro entre religiões. Pois, a "fé fundamental" associada à noção de preocupação última é, ao mesmo tempo, segundo a compreensão de Tillich, uma "fé abismal" - isto é, sobre a qual nada pode se dar positivamente, porque nessa dinâmica se assenta a ambiguidade da fé, do sagrado e da religião como um todo.

Tillich aponta para essa questão ao analisar o movimento ecumênico, a partir do conceito que acima analisamos, de Comunidade Espiritual (2005, p. 620). Ele enfatiza que toda manifestação da Comunidade Espiritual se dá como experiência de vida sem ambiguidade, ainda que de modo fragmentário. Uma das faces da ambiguidade do cristianismo, nesse caso, é a desunião em detrimento da unidade essencial que lhe é própria, como manifestação da Comunidade 
Espiritual. Ao mesmo tempo, esta última também se faz presente fragmentariamente - na luta e esforços ecumênicos por unidade.

O exemplo mais notável destas tentativas em nosso tempo é a atuação do Conselho Mundial de Igrejas. O movimento ecumênico, do qual ele é o representante oficial, expressa poderosamente a consciência do predicado da unidade em muitas igrejas contemporâneas. (...) Mas nem o movimento ecumênico nem qualquer outro movimento futuro conseguirão superar a ambiguidade de unidade e divisão na existência histórica das igrejas. (...) A dinâmica da vida, a tendência de preservar o sagrado mesmo quando ele se torna obsoleto, as ambiguidades implícitas na existência sociológica das igrejas e, sobretudo, a crítica profética e a exigência de reforma causariam novas divisões, muita das quais Espiritualmente justificadas. A unidade das igrejas, à semelhança de sua santidade, tem caráter paradoxal. É a igreja dividida que é a igreja una (TILLICH, 2005, 620-621).

Ainda que a análise se restrinja ao ecumenismo confessional cristão da década de 1960, o argumento central oferece algo para pensar a ecumene interreligiosa como manifestação fragmentária da Comunidade Espiritual. Nota-se que ao alistar as razões da impossibilidade de realização plena dessa unidade, Tillich aponta para aqueles aspectos relativos à ambiguidade da fé, da religião e do sagrado expostos acima - como expressões da "dinâmica da vida". Quer dizer, o juízo do incondicional sobre toda a realidade condicionada se dirige aqui também ao ecumenismo como manifestação da Comunidade Espiritual. A afirmação de Tillich de que toda "grandeza auto-afirmada no âmbito do sagrado é demoníaca", válida também "para uma igreja que reivindica representar em sua estrutura a Comunidade Espiritual de uma maneira não-ambígua" (2005, p. 687), se estende a toda religião e, por conseguinte, ao encontro entre religiões tomado como manifestação da Comunidade Espiritual.

Isso não significa, evidentemente, um absoluto interdito à iniciativa ecumênica e mesmo a uma teologia inter-religiosa. Para Tillich, trata-se de assumir o risco do paradoxo do incondicional absolutamente. A questão é, então, certificarmo-nos, como propõe Geffré, das bases teológicas e do modelo adequado 
para tal. Nesse sentido, o retorno ao argumento kenótico é novamente significativo. A análise de Tillich acima citada indica o que efetivamente vai ao encontro da proposta de Geffré, de tomar a noção de preocupação última como "um conceito de religião que possa justificar o encontro das religiões" (GEFFRÉ, 2013, p. 111). Novamente, é o caráter paradoxal do incondicional que tem de ser assumido com todos os riscos implicados, através da superação de uma objetivação da própria unidade fundamental entre religiões. Esta configuraria uma idolatrização e demonização da unidade como manifestação da Comunidade Espiritual. Quer dizer, a partir da preocupação última, religiões se encontrariam no vazio comum e constitutivo da incondicionalidade da qual participam parafraseando Tillich: é a religião dividida que é a religião una.

Assim, ao eleger o conceito de preocupação última como conceito central para uma teologia inter-religiosa, a dimensão crítica do princípio incondicional, que lhe é inerente e inealienável, tem de ser assumida. A visão que Tillich tem de religião não é boa, nem má: é ambígua. Para nossa análise, nesse ponto, Geffré não dá a devida atenção à implicação do paradoxo nesses termos, e assim, investe numa percepção em que a dimensão da ambiguidade parece ausente: “a experiência do sagrado, portanto, como experiência da preocupação última, que é o ponto de convergência de todas as religiões e que nos fornece um critério comum para o diálogo inter-religioso" (GEFFRÉ, 2013, p. 113).

Nesse sentido, e para finalizar, deveríamos lembrar do conceito correlativo ao princípio protestante, que é o de substância católica, tal como o próprio Geffré evoca ao concluir seu capítulo (2013, p. 116). Com Tillich, lembramos que a relação entre ambos, do mesmo modo como toda correlação que ele desenvolve, é marcada pelo paradoxo do incondicional:

O princípio protestante (...) sozinho não é suficiente; também é necessária a 'substância católica', a corporificação concreta da Presença Espiritual; mas ele é o critério da demonização (e profanização) desta corporificação. O princípio protestante expressa a vitória do Espírito sobre a religião (TILLICH, 2005, p. 687-688). 


\section{Conclusão}

O ponto de partida de nossa análise foi a justificativa do autor de De Babel a Pentecostes, quanto à exigência, quarenta anos após o Concílio Ecumênico do Vaticano II, de uma teologia que corresponda efetivamente ao desafio do pluralismo religioso contemporâneo. O diálogo inter-religioso impõe exigências para o cristianismo que, a partir de si mesmo, exige uma unicidade absoluta. Ao que parece imponderável, Geffré responde a partir do próprio fundamento da teologia cristã, que cobra simultaneamente amor ao mundo e fidelidade ao Cristo. A constatação de uma insuficiência teológica em toda proposta que comprometa um dos lados dessa tensão de exigências leva Geffré a propor as linhas básicas de uma teologia inter-religiosa.

Para desenvolvê-las, vimos que Geffré recorre a conceitos fundamentais da filosofia da religião e teologia da cultura de Paul Tillich. É digno de nota o fato de Claude Geffré tomar como referência a obra de um teólogo protestante para sustentar sua proposta, sobretudo pelo resultado obtido. Foi o que analisamos na leitura e no tratamento de cada conceito realizado no texto de Geffré, procurando detalhar aspectos implícitos a partir da análise das referências deste à Teologia sistemática e a outros textos importantes da obra de Tillich. Um dos resultados da análise é o relevo ao conceito de paradoxo, que Geffré bem percebe associado à cristologia tillichiana, e ao conceito de incondicional, definindo-os como fundamentais no pensamento de Tillich.

O destaque crítico, por sua vez, recai sobre o conceito de preocupação última, que o autor elege como critério para uma teologia inter-religiosa calcada no encontro e diálogo entre religiões. Nesse sentido, desenvolvemos um argumento que remete ao caráter paradoxal no qual o conceito de procupação última se assenta, identificando a ausência de sua qualidade crítica, cujas implicações precisam ser consideradas. 
O problema, como vimos, é o seguinte: se, a partir do conceito de preocupação última, Tillich desenvolve um critério para lidar teologicamente com a ambiguidade da fé, da religião e da dinâmica do sagrado correlativamente, então, ao tomar esse conceito como base para uma teologia inter-religiosa, essa dimensão crítica deveria também indicar as ambiguidades inerentes ao diálogo interreligioso como manifestação fragmentária da Comunidade Espiritual, tal como Tillich a define.

Com base no argumento de Tillich, o pluralismo religioso implica pensar que cada religião, para ser efetiva e viva, precisa incondicionalmente realizar para si o sagrado. A despeito de ocorrerem de modo dinâmico, essas realizações de sentido e demarcações de fronteiras simbólicas se sobrepõem àquelas realizadas e delimitadas por outras religiões. Significa que o sagrado entre as religiões não se implica necessariamente; pelo contrário, enquanto símbolo, ele se realiza na esfera do condicionado de umas para com outras religiões. De fato, encontramos o pressuposto em Tillich quanto a uma universalidade da preocupação última. Mas, ao mesmo tempo, a própria noção determina um princípio crítico - de ultimidade, ou incondicionalidade - que não pode ser negligenciado.

Assim, concluímos nossa análise sublinhando, a partir de Tillich, esse aspecto que nos ajuda a ampliar ainda mais a percepção do problema motivador quanto ao desafio teológico do pluralismo religioso: a unidade das religiões está nas suas particularidades e naquilo que as divide, e o diálogo teria lugar a partir de uma kénosis comum, que as fundamenta e, ao mesmo tempo, as coloca sob o juízo da realidade da qual testemunham. 


\section{REFERÊNCIAS}

BÍBLIA Sagrada: nova versão internacional. São Paulo: Vida, 2000.

BOSS, Marc. Tillich in dialogue with Japanese Buddhism: a paradigmatic illustration of his approach to inter-religious conversation. In: MANNING, Russel Re (ed). The Cambridge companion to Paul Tillich. Cambridge, UK: Cambridge University Press, 2009, p. 254-272.

GEFFRÉ, Claude. Crer e interpretar: a virada hermenêutica da teologia. Petrópolis: Vozes, 2004.

GEFFRÉ, Claude. De Babel a Pentecostes: ensaios de teologia inter-religiosa. São Paulo: Paulus, 2013.

PALMER, Michael. Paul Tillich's theology of culture. In: PALMER, Michael (ed). Paul Tillich Main works/Hauptwerke, v.2. Writings in the philosophy of culture. Berlim/New York: Evangelisches Verlangswerk. De Gruyter, 1990. p. 1-32.

REIJNEN, Anne Marie. Tillich's christology. In: MANNING, Russel Re (ed). The Cambridge companion to Paul Tillich. Cambridge, UK: Cambridge University Press, 2009. p. 56-73.

RIBEIRO, Claudio de Oliveira. Pluralismo e libertação. São Paulo: Paulinas, 2014.

TILLICH, Paul. Dinâmica da fé. 6 ed. Leopoldo: Sinodal, 2001.

TILLICH, Paul. Religion and secular culture (1946); Existencialist aspect of modern art (1956); Protestantism and the contemporary style in the visual arts (1957). In: PALMER, M. (ed.). Paul Tillich Main works/Hauptwerke, v.2. Writings in the philosophy of culture. Berlim/New York: Evangelisches Verlangswerk. De Gruyter, 1990, p. 197-207; p. 269-79; p. 297-302.

TILLICH, Paul. Die Überwindung des Religionsbegriffs in der Religionphilosophie (1922); Religionphilosophie (1925). In: RATSCHOW, Carl H.; CLAYTON, John. (ed.) Paul Tillich Main Works / Haupwerke, v.4. Writings on the philosophy of religion. Berlin, New York: Evangelisches Verlangswerk. De Gruyter, 1987, p. 117-170.

TILLICH, Paul. Teologia sistemática. 5 ed. São Leopoldo: Sinodal. EST, 2005. 